\title{
Homenagem ao professor Gilberto Machado de Almeida
}

\author{
Felix H. Pahl ${ }^{1}$ \\ ${ }^{1}$ Hospital do Servidor Público Estadual - SP; Hospital Sírio Libanês, \\ São Paulo, SP, Brasil
}

Arq Bras Neurocir 2015;34:265-266.
Address for correspondence Felix H. Pahl., DFV neuro, SP, Brasil, (e-mail: priscila.cavalcante@sbn.com.br).

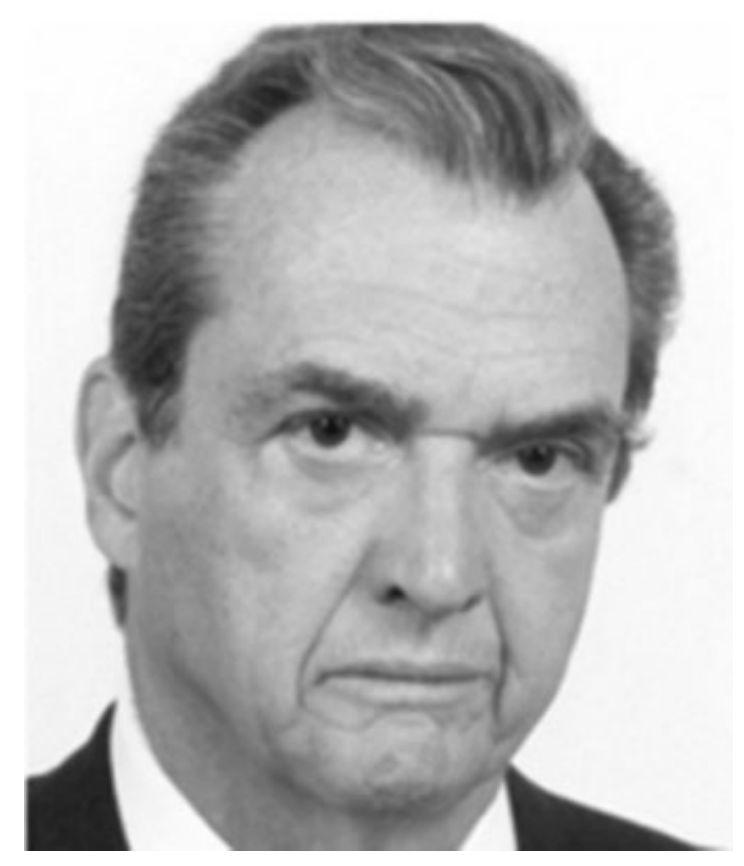

Fig. 1 Professor Gilberto Machado de Almeida.

Sua conduta, isenta de interesses pessoais em relação aos pacientes e familiares, colegas e fornecedores, era um exemplo a ser seguido pelos mais novos.

Muitos expoentes da neurocirurgia nacional foram formados por ele, como Manoel J. Teixeira, Mario Taricco, Hamilton Matushita, Guilherme Carvalhal Ribas, Eduardo Vellutini, Paulo Henrique Aguiar, entre outros.

Publicou quarenta artigos em revistas indexadas e vários capítulos de livros. Entre os artigos, o mais importante foi sobre cirurgia dos aneurismas de oftálmica, publicado na Surgical Neurology em 1976, amplamente citado.

Do ponto de vista associativo, foi presidente do congresso latino americano de neurocirurgia em 1983. Foi presidente da Sociedade Brasileira de Neurocirurgia (SBN) entre 1990 e 1992, e do Congresso Brasileiro de Neurocirurgia (CBNC) em

Copyright $\odot 2015$ by Thieme Publicações License terms Ltda, Rio de Janeiro, Brazil
DOI http://dx.doi.org/ 10.1055/s-0035-1565006. ISSN 0103-5355. published online October 28, 2015
Gostaria de agradecer imensamente a oportunidade de prestar esta homenagem ao nosso querido professor Gilberto Para quem não o conheceu, "O Professor", como era chamado, foi um dos maiores líderes da neurocirurgia brasileira no seu tempo.

Hospital das Clínicas (HC) em São Paulo. Naquele momento, o HC representava uma das residências médicas de O prestígio no país.

passava por ele. A decisão final era sempre a dele, apesar de a clínica contar com valiosos assistentes, como Newton Do位 para que conseguissem finalizá-la com êxito.

vascular, base de crânio, tumores, infantil, funcional. Isto vários serviços no Brasil. 
1992. Foi amigo pessoal de lideranças neurocirúrgicas internacionais, como Charles Drake, Eugene Flamm, Bennet Stein, Madjid Samii.

Foi casado com Elenice, eminente escritora de literatura infantil com 28 livros publicados, com quem teve quatro filhos (Eduardo, Otávio, Gil e Renato), dois deles se tornaram médicos.

Era um líder da família.

Gostava de esportes, criava cavalos.

Após longa tentativa de criar a disciplina de neurocirurgia na Faculdade de Medicina da Universidade de São Paulo (FM-USP), conseguiu a vaga e a abertura do concurso em abril de 1990. Acabou sendo vencido; quem ficou com a cátedra foi o professor Raul Marino Jr.

Um pouco antes do concurso, perdeu a sua esposa Elenice, vitimada por um câncer, e logo após o seu filho Gil.

Como pessoa de personalidade forte, focado na profissão, O Professor recuperou-se, dedicando-se à SBN e ao
CBNC, à neurocirurgia do Hospital Nove de Julho, em SP junto com os doutores Milton Shibata e Eduardo Bianco -, e ao cargo de professor convidado na Faculdade de Medicina de Botucatu.

Casou-se novamente com Maia e nos últimos anos viveu em Florianópolis, dedicando-se à criação de pássaros.

Gilberto Machado de Almeida era um homem de princípios, justo, honesto e brilhante neurocirurgião. Faço minhas as palavras de Mario Sergio Cortella: "Infeliz é o homem que não ensina o que sabe e não pratica o que ensina. Virtuosos e felizes são os homens que têm generosidade mental (e portanto ensinam o que sabem) e honestidade moral (e portanto praticam o que ensinam)."

Sem dúvida, O Professor Gilberto Machado de Almeida foi um homem virtuoso e feliz em sua vida, e os que tiveram o prazer da sua convivência só podem agradecer por este privilégio. 